\title{
DESA TANGGUH DAN BERDAYA DALAM MENGHADAPI COVID-19 DI ERA KEBIASAAN BARU
}

\author{
Umi Kalsum*, Guruh Setyo Pambudi, Ahmad Luayyi Nur Rozikin, Nahdlatul Ummah, \\ Bayu Wibowo, Seto Tri Pambudi, Moh. Ridho, Mahayu Hikmatul Haq, Abdul Wadud \\ Wahab Hasbullah, Dimas Al Buchori, M. Nawas Syarif
}

Fakultas Peternakan, Universitas Islam Malang

*Korespondensi email: kalsum2008@unisma.ac.id

\begin{abstract}
ABSTRAK
Virus Covid-19 merujuk pada singkatan dari "Coronavirus Disease 2019" atau penyakit yang disebabkan oleh virus Corona pada 2019, masih menjadi topik perbincangan yang hangat sejak awal kemunculannya pada bulan Desember 2019 di China. Hampir kurang lebih 215 Negara di Dunia terjangkit virus corona termasuk Indonesia dan memicu keresahan ekonomi secara global. Program KKN-PPM ini bertujuan untuk menjadikan desa tangguh dan berdaya dalam menghadapi Covid-19 di era kebiasaan baru. Melalui bantuan berupa bibit sayuran dan bibit lele dalam upaya mengoptimalkan ketersediaan dan stabilitas ketahanan pangan. Selain itu bantuan untuk pencegahan penularan Covid-19 melalui pembagian hand sanitizer dan masker kain. Diharapkan dari kegiatan ini masyarakat mampu meningkatkan kepedulian, empati, produktifitas, dan kreatifitas dari permasalahan yang sedang dihadapi. Program kegiatan KKN-PPM Tematik ini dibagi menjadi 3 tahap diantaranya: sosialisasi, penyuluhan serta pendampingan dan evaluasi. Dalam pelaksanaannya bekerja sama dengan pihak desa selaku tuan rumah, dan masyarakat sebagai peserta, sehingga program kerja dari KKN-PPM ini dapat berjalan dan berkelanjutan. Kesimpulan dari kegiatan ini sebagai langkah antisipasi dampak Pandemi Covid-19, di mana harga pangan yang tinggi dapat mempengaruhi kebutuhan pangan masyarakat. Dan masyarakat juga berperan dalam mengurangi potensi penularan Covid-19.
\end{abstract}

Kata Kunci: berdaya; covid-19; desa; tangguh.

\section{PENDAHULUAN}

Virus Covid-19 merujuk pada singkatan dari "Coronavirus Disease 2019" atau penyakit yang disebabkan oleh virus Corona pada 2019, masih menjadi topik perbincangan yang hangat sejak awal kemunculannya pada bulan Desember 2019. Bagaimana tidak, virus yang pertama kali ditemukan di China ini, telah menginfeksi jutaan orang di dunia dan juga memicu keresahan ekonomi secara global (Agustino, 2020; Rizky et al., 2020). Virus Covid19 dapat menyerang sistem pernapasan, sehingga mengakibatkan penderitanya mengalami sesak nafas, pnemunia akut dan hingga berujung kematian (Ilpaj \& Nurwati, 2020; Siagian, 2020). Menurut Purnamasari \& Raharyani (2020) virus corona telah menyebar lebih dari 215 Negara di dunia, termasuk Indonesia. Perkembangan kasus infeksi corona terjadi begitu cepat sejak terkonfirmasinya pasien positif pertama pada tanggal 2 Maret 2020 di Indonesia. Hingga kini, per tanggal 10 Agustus 2020, data dari worldometer menunjukkan ada 127.083 kasus terinfeksi virus corona di Indonesia (Putri, 2020). 
Dimasa Covid-19 ini, masyarakat Indonesia merasakan dampaknya, mulai dari berbagai macam aspek seperti: aspek ekonomi, aspek kesehatan, aspek pendidikan, dan aspek lain-lainnya (Jureid, 2020). Dampak ini, berakibat merubah kebiasaan masyarakat Indonesia yang sebelumnya tidak pernah dilakukan, sehingga mereka harus membuat sebuah kebiasaan baru atau kita sebut dengan New Normal (Bahri \& Arafah, 2020; Puspa, Agung, \& Mertayasa, 2020). Demi terciptanya desa tangguh dan berdaya dalam menghadapi Covid-19 merupakan harapan kami selaku mahasiswa KKN-PPM Kelompok 47 yang terbagi pada lokasi daerah berbeda di Jawa Timur.

Berdasarkan survei yang telah dilakukan oleh Mahasiswa Universitas Islam Malang KKN-PPM Kelompok 47 Tematik berbasis “Desa Tangguh dan Berdaya Covid-19” yang terbagi pada lokasi daerah berbeda mulai dari Desa Patokpicis, Kabupaten Malang; Desa Bancelok, Kabupaten Sampang dan Desa Genteng Kulon, Kabupaten Banyuwangi. Ditemukan warga dari lokasi daerah masing-masing masih ada yang belum mampu beradaptasi dengan keadaan yang sedang terjadi, karena mungkin kurang adanya sosialisasi serta edukasi yang tepat.

Salah satu dinamika yang sedang dialami karena Pandemi Covid-19 antara lain, ialah hilangnya mata pencaharian, ketahanan pangan menurun dan kesehatan atau pun kebersihan lingkungan karena pembatasan sosial menjadi tidak stabil (Pratiwi, Hamdiyah, \& Asnuddin, 2020). Pada kesempatan kali ini kami selaku Mahasisiwa Universitas Islam Malang KKN-PPM Kelompok 47 berharap setiap desa mampu menjadi "Desa Tangguh dan Berdaya, dalam Menghadapi Covid-19". Dalam masa seperti ini, perlu upaya peningkatan dan peran penting pada setiap elemen masyarakat. Bersama-sama kita bangun kerja sama demi terciptanya produktifitas dan ketahanan pangan yang cukup, agar kita dapat saling membantu dan mendukung sesama dalam menghadapi Covid-19.

Dari gagasan tersebut, maka kami menawarkan suatu kegiatan kepada masyarakat desa melalui bantuan bibit sayuran dan bibit lele. Hal ini bertujuan sebagai salah satu upaya kami, dalam mengoptimalkan ketersediaan dan stabilitas ketahanan pangan. Disamping itu kami juga melakukan pembuatan hand sanitizer yang ekonomis dan ramah lingkungan, serta pembagian masker kain sebagai strategi kami dalam menjaga diri sendiri dan untuk produktifitas di lingkungan masyarakat. Keluaran dari program kami nantinya dapat memberdayaan masyarakat di Desa Patokpicis, Kabupaten Malang; Desa Bancelok, Kabupaten Sampang dan Desa Genteng Kulon, Kabupaten Banyuwangi. Agar meningkatnya sumber daya dan mampu mengoptimalkan potensi yang ada di Desa tersebut. Sehingga pada akhirnya, mampu meningkatkan ketahanan pangan dan kesehatan atau pun kebersihan lingkungan sesuai dengan kondisi Pandemi Covid-19 sekarang ini.

Manfaat yang diharapkan dari kegiatan ini adalah mampu meningkatkan kepedulian, empati, produktifitas dan kreatifitas dari permasalahan yang sedang dihadapi masyarakat. melalui pendampingan program ini (Martino, Sulistyowati, \& Purnomo, 2018). pencapaian yang diinginkan adalah terjadi perubahan perilaku serta pandangan hidup baik bagi mahasiswa maupun terhadap masyarakat setempat. Serta mampu memberikan pengalaman dan menerapkan ilmu yang telah kami dapatkan selama duduk dibangku perkuliahan kepada masyarakat di Desa Patokpicis, Kabupaten Malang; Desa Bancelok, Kabupaten Sampang dan Desa Genteng Kulon, Kabupaten Banyuwangi.

\section{METODE}

Kegiatan KKN-PPM Tematik ini bertempat di 3 daerah dengan wilayah berbeda mulai dari Desa Patokpicis, Kabupaten Malang; Desa Bancelok, Kabupaten Sampang dan Desa Genteng Kulon, Kabupaten Banyuwangi yang dilaksanakan dalam kurun waktu satu bulan lamanya mulai dari 03 agustus 2020 hingga 03 september 2020. Program pada kegiatan KKN- 
PPM Tematik ini dibagi 3 tahap diantaranya: sosialisasi, penyuluhan serta pendampingan dan evaluasi. Dalam melaksanakan kegiatan ini perlu adanya kerja sama dengan pihak desa selaku tuan rumah, dan masyarakat sebagai peserta, sehingga program kerja dari KKN-PPM ini dapat berjalan dan berkelanjutan.

\section{HASIL DAN PEMBAHASAN}

Pada kegiatan KKN-PPM yang merupakan program pengabdian ini dibagi menjadi 3 tahap, antara lain: Tahap 1 adalah tahap sosialisasi, Tahap 2 adalah penyuluhan serta pendampingan, dan Tahap 3 adalah evaluasi. Untuk kegiatan tahap 1 diawali dengan sosialisai program dengan masyarakat desa tanpa mengumpulkan kerumunan yang artinya dilakukan dengan cara mengunjungi warga di rumahnya masing-masing. Program pengabdian dipaparkan untuk memberi gambaran secara menyeluruh mengenai program kegiatan oleh tim pengabdi. Warga sangat antusias dengan program ini. Hasil dari sosialisasi ini adalah warga desa dapat membangun interaksi dan kerja sama mengenai program yang akan dijalankan, agar terwujudnya sinergis antara warga desa dengan tim pengabdi.

Tahap 2 dari program kegiatan adalah penyuluhan serta pendampingan yang telah dilaksanakan dengan warga desa setempat. Pada tanggal yang telah ditetapkannya pelaksanaan kegiatan penyuluhan kami mengajarkan metode dan informasi lebih lanjut mengenai Covid-19, sehingga masyarakat setempat dapat lebih faham dan mengerti apa yang harus dilakukan. Harapan warga dari kegiatan seperti ini, dapat menambah ilmu dan dapat diaplikasikan dalam ketahanan pangan melalui pembagian bantuan bibit sayuran dan bibit lele serta kebersihan diri dan lingkungan melalui pembagian bantuan hand sanitizer dan masker yang dibagikan di rumah masing-masing warga. Untuk proses pemberian informasi dan metode pembuatan dilakukan pertama kali oleh tim pengabdi bersama warga setempat. Selanjutnya kami memantau dan mengaplikasikannya serta melihat bagaimana keberlanjutan dari progam kami.

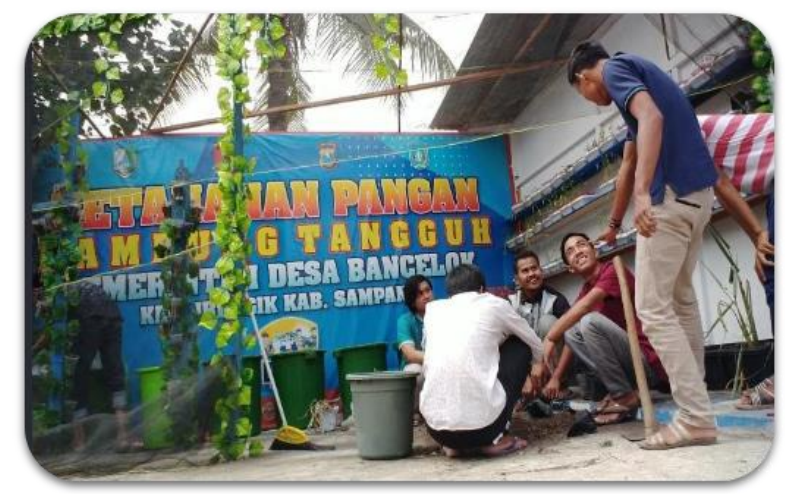

Gambar 1. Bibit sayuran yang akan dimasukkan ke dalam polybag (dok. KKN Kel. 47)

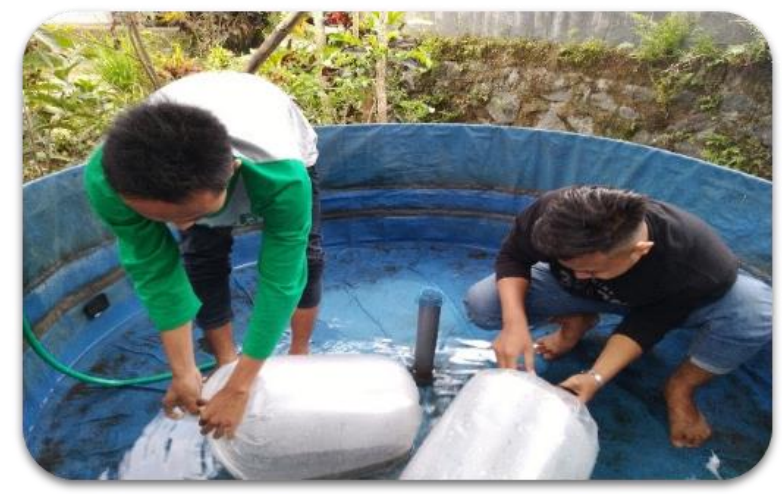

Gambar 2. Peletakan bantuan bibit lele di kolam (dok. KKN Kel. 47) 
Pada Desa Bancelok, Kecamatan Torjun, Kabupaten Sampang melalui bibit sayuran sebagai ketahanan pangan, untuk sayuran yang diplilih adalah kangkung dan sawi. Pemilihan kedua jenis sayuran tersebut didasari alasan bahwa kedua jenis sayuran yang banyak dikonsumsi dan mempunyai nilai jual yang baik. Selain mudah dibudidayakan juga memiliki masa panen yang singkat yaitu hanya tiga sampai empat pekan. Bibit sayuran yang awalnya telah disemai akan dipindahkan ke media tanam di dalam polybag sebelum dibagikan kepada masyarakat. Sedangkan, di Desa Patokpicis, Kecamatan Wajak, Kabupaten Malang untuk ketahanan pangan melalui bantuan bibit lele yang berjumlah 5.000 ekor. Di sini bibit lele yang akan dikembangkan di desa tersebut melalui kerjasama dengan mitra Bapak Kamituo dan Bapak Kades selaku tuan rumah serta sebagai fasilitatornya.

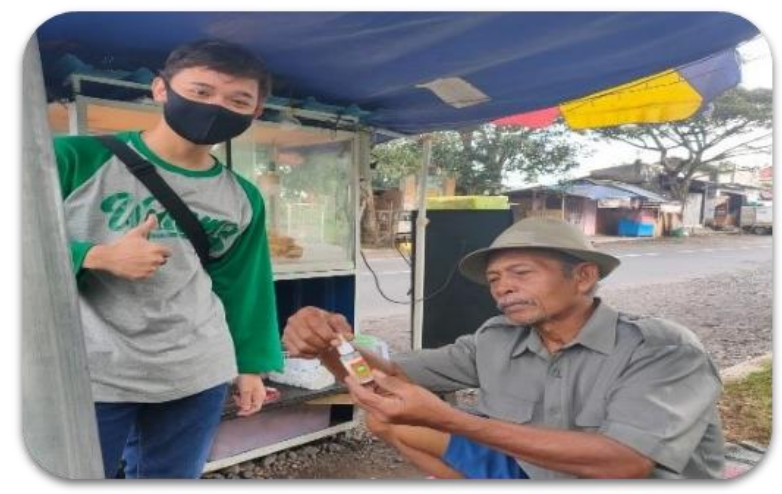

Gambar 3. Sosialisasi dan edukasi pada bantuan Hand Sanitizer (dok. KKN Kel. 47)

Sedangkan untuk pencegahan penularan Covid-19 di desa masing-masing tim pengabdi, hal yang sama dilakukan melalui bantuan hand sanitizer dan masker. Hand sanitizer merupakan cairan pembersih tangan yang tidak memerlukan air untuk membilasnya. Fungsinya sebagai pembunuh virus dan bakteri yang menempel pada tangan. Untuk pembuatan hand sanitizer sendiri terbuat dari bahan antara lain cairan Dettol dengan takaran setengah tutup botol dan selanjutnya dituang pada baskom yang sudah terisi dengan akuades. Kemudian, dicampurkan dengan air mawar sebagai pewangi agar supaya bahan pertama yaitu cairan Dettol baunya tidak terlalu menyengat. Setelah itu, dituang ke dalam botol spray berukuran $60 \mathrm{ml}$. Dilansir dari (WHO, 2010) untuk pembuatan hand sanitizer menggunakan bahan antara lain seperti alkohol 70\%, gliserol 98\%, $\mathrm{H}_{2} \mathrm{O}_{2} 3 \%$ dan akuades. Bahan-bahan ini memiliki fungsi sebagai antimikroba, disertai bahan yang dapat menjaga kelembapan kulit yaitu berasal dari gliserol.

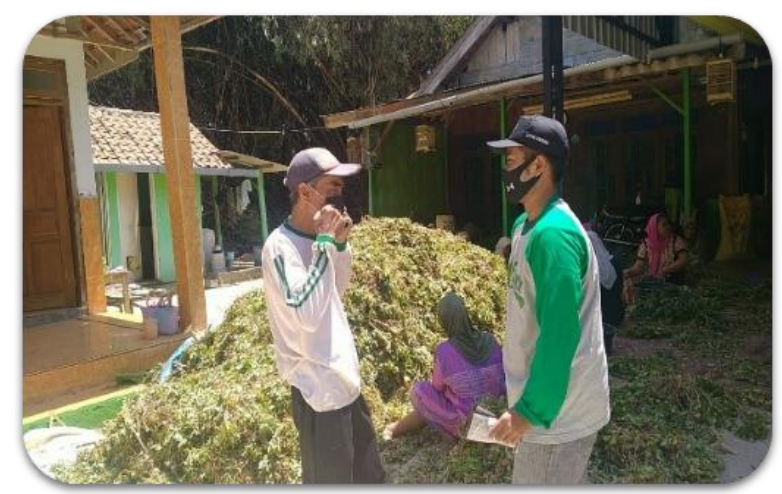

Gambar 4. Sosialisai dan edukasi pada bantuan masker (dok. KKN Kel. 47) 
Dan untuk bantuan masker, jenis masker yang dibagikan kepada warga berupa masker kain. Masker kain menjadi alternatif lain yang diperuntukkan bagi masyarakat mengingat masker bedah cenderung langka di pasaran. Bagi masyarakat yang memiliki gejala Covid-19 bisa menggunakan masker kain untuk mencegah droplet maupun partikel yang menjadi airbone agar tidak menularkan ke orang lain. Di samping itu, masker kain bisa dibuat dengan mudah di rumah. Terpenting adalah menggunakan kain yang nyaman dipakai, desainnya bisa dimasuki tisu, dan bisa menahan percikan droplet. Kami juga menyampaikan kepada masyarakat bahwa masker kain boleh dipakai berulangkali, dengan catatan harus dicuci secara tepat. Mencuci masker kain tidaklah sulit, yaitu dengan menggunakan deterjen dan dibasuh dengan air hangat sebagai upaya pencegahan tertular dari virus.

Tahap 3 adalah evaluasi, dampak dari kegiatan ini mulai dari bantuan bibit sayuran dan bibit lele adalah dapat diaplikasikannya dengan baik dan benar supaya mampu memenuhi kebutuhan pangan secara mandiri, menekan biaya pangan keluarga, dan tentu membentuk ketahanan pangan di tingkat desa. Sedangkan, untuk pencegahan penularan Covid-19 dengan adanya bantuan hand sanitizer dan masker dapat bermanfaat dalam mengurangi potensi penularan virus Covid-19 di mana warga selama pandemi Covid-19 ini tidak hanya berkegiatan di dalam rumah saja, tetapi juga di luar rumah yang terkadang memerlukan kontak langsung.

\section{KESIMPULAN}

Dalam kegiatan ini dapat ditarik kesimpulan sebagai langkah antisipasi dampak Pandemi Covid-19 terhadap ketersediaan dan stabilitas ketahanan pangan. Di mana harga pangan yang tinggi dapat mempengaruhi kebutuhan pangan masyarakat. Dan penyediaan bantuan pada kesehetan atau pun kebersihan lingkungan berupa hand sanitizer dan masker untuk masyarakat dapat membantu serta bermanfaat dalam mengurangi potensi penularan Covid-19.

\section{UCAPAN TERIMA KASIH}

Ucapan terimakasih disampaikan kepada Kepala Desa beserta Perangkat Desa di daerah masing-masing mahasiswa KKN-PPM kelompok 47 yang telah menerima dan membantu mahasiswa peserta KKN-PPM Tematik selama kurun waktu 1 bulan yang dimulai dari tanggal 03 Agustus 2020 hingga 03 September 2020 dalam menjalankan progam kerja. Ucapan terimakasih juga disampaikan kepada Ketua LPPM Universitas Islam Malang yang telah memberikan kesempatan dan terlaksananya kegiatan KKN-PPM Tematik.

\section{DAFTAR RUJUKAN}

Agustino, L. (2020). Analisis Kebijakan Penanganan Wabah Covid-19: Pengalaman Indonesia. Jurnal Borneo Administrator, 16(2), 253-270. https://doi.org/10.24258/jba.v16i2.685

Bahri, S., \& Arafah, N. (2020). Analisis Manajemen Sdm Dalam Mengembangkan Strategi Pembelajaran Di Era New Normal. Interdisciplinary Journal of Islamic Education, 1(1), 20-40.

Retrieved from https://scholar.google.co.id/scholar?start=0\&q=manajemen+sekolah+di+era+pand emi\&hl=id\&as_sdt=0,5

Ilpaj, S. M., \& Nurwati, N. (2020). Analisis Pengaruh Tingkat Kematian Akibat Covid-19. Jurnal Pekerjaan Sosial, 3(1), 16-28. https://doi.org/10.24198/focus.v3i1.28123

Jureid. (2020). Ekonomi Syariah Sebagai Alternatif Kesejahteraan Ekonomi Masyarakat Pada Era Covid-19. Jurnal Kajian Ekonomi Dan Kebijakan Publik, 5(2), 224-236. Retrieved from http://jurnal.pancabudi.ac.id/index.php/jepa/article/view/910 
Martino, Y. A., Sulistyowati, E., \& Purnomo, Y. (2018). Model Pemberdayaan Santri Ponpes Al-Hidayah Batu Malang Sebagai Kader Kesehatan Berbasis Terapi Herbal. Jurnal Inovasi Hasil Pengabdian Masyarakat (JIPEMAS), 1(2), 86-93. https://doi.org/10.33474/jipemas.v1i2.1514

Pratiwi, W. R., Hamdiyah, H., \& Asnuddin, A. (2020). Deteksi Dini Masalah Kesehatan Reproduksi Melalui Pos Kesehatan Remaja. Jurnal Inovasi Hasil Pengabdian Masyarakat (JIPEMAS), 3(1), 87-94. https://doi.org/10.33474/jipemas.v3i1.5035

Purnamasari, I., \& Raharyani, A. E. (2020). Tingkat Pengetahuan dan Perilaku Masyarakat Kabupaten Wonosobo Tentang Covid-19. Jurnal Ilmiah Kesehatan, 10(1), 33-42. Retrieved from https://ojs.unsiq.ac.id/index.php/jik/article/view/1311

Puspa, I. A. T., Agung, I. G. N. P., \& Mertayasa, I. K. A. (2020). SENI MAJEJAITAN DAN METANDING SEBAGAI ATRAKSI WISATA DI ERA NEW NORMAL. Pariwisata Budaya: Jurnal Ilmiah Pariwisata Agama Dan Budaya, 5(2), 82-90. https://doi.org/10.25078/pba.v5i2.1798

Putri, N. H. (2020). Update Perkembangan Terkini Penyebaran COVID-19 di Indonesia. SehatQ. Jakarta. Retrieved from https://www.sehatq.com/artikel/perkembangan-terkinisituasi-penyebaran-virus-corona-di-indonesia

Rizky, S., Trisiana, A., Ajrur, F., Algileri, L., Syaibani, I., \& Nur, S. (2020). Menumbuhkan Kesadaran Masyarakat Indonesia Untuk Memutus Rantai Penyebaran Wabah Covid19. Jurnal Ilmiah Kajian Pendidikan Kewarganegaraaan, 9(1), 51-62. Retrieved from http://ejurnal.unisri.ac.id/index.php/glbctz/article/view/...\%0ADiterima:

Siagian, T. H. (2020). Mencari Kelompok Beresiko Tinggi Terinfeksi Virus Corona Dengan Discourse Network Analysis. Jurnal Kebijakan Kesehatan Indonesia: JKKI, 09(02), 98. https://doi.org/10.22146/jkki.55475 